\title{
Surfaces
}

\section{THE INSTITUTIONS OF CULTURAL STUDIES}

\section{Ronald Schleifer}

Volume 2, 1992

ACTES DU COLLOQUE « REPENSER LA CULTURE » ACTS OF THE CONFERENCE "RETHINKING CULTURE"

URI : https://id.erudit.org/iderudit/1065233ar

DOI : https://doi.org/10.7202/1065233ar

Aller au sommaire du numéro

\section{Éditeur(s)}

Les Presses de l’Université de Montréal

ISSN

1188-2492 (imprimé)

1200-5320 (numérique)

Découvrir la revue

Citer ce document

Schleifer, R. (1992). THE INSTITUTIONS OF CULTURAL STUDIES. Surfaces, 2. https://doi.org/10.7202/1065233ar
Résumé de l'article

Une réflexion sur la problématique disciplinaire de l'analyse des pratiques culturelles. Les modalités de l'institutionnalisation d'une entreprise théorique et analytique. Mise en évidence de l'établissement d'un programme en cultural studies à l'Université d'Oklahoma.
Copyright (c) Ronald Schleifer, 1992

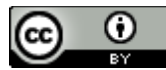

Ce document est protégé par la loi sur le droit d'auteur. L'utilisation des services d’Érudit (y compris la reproduction) est assujettie à sa politique d'utilisation que vous pouvez consulter en ligne.

https://apropos.erudit.org/fr/usagers/politique-dutilisation/ 
CONFERENCE PROCEEDINGS

"RETHINKING CULTURE"

THE INSTITUTIONS OF CULTURAL STUDIES

$\underline{\text { Ronald Schleifer }}$

This paper was originally delivered at the conference Rethinking Culture held at the University of Montreal, April 3-5, 1992. The organizers would like to thank the following sponsors for their financial support:

Social Science Research Council of Canada

Faculty of Arts and Sciences, University of Montreal

Vice Rector for Teaching and Research, University of Montreal

Department of Comparative Literature, University of Montreal

\author{
Alitalia
}

ABSTRACT

An account of the disciplinary problematic of cultureal studies. How does a theoretical and analytic enterprise take on an institutional form? Special reference to the establishment of a program in cultural studies at the University of Oklahoma. 


\section{RÉSUMÉ}

Une réflexion sur la problématique disciplinaire de l'analyse des pratiques culturelles. Les modalités de l'institutionnalisation d'une entreprise théorique et analytique. Mise en évidence de l'établissement d'un programme en cultural studies à l'Université d'Oklahoma.

\section{I}

The title of my paper, "The Institutions of Cultural Studies," presents my contention that institutions of cultural studies are necessarily plural because cultural studies is (or "are") necessarily local. Yet I am trying, in this paper and in my own ongoing activities of reading and understanding, to develop a sense of the local that is not parochial in order to describe an alternative to what the conservative polemicist, Roger Kimball, calls "universal human interest" (1992: 69) that will oppose transcendental universalism with something that is not simply the random fragments of local particularities -the pluralism that Geralf Graff and Samuel Weber describe in relation to institutions.

Lately, I've been trying to development terms that breach this seeming absolute opposition. For instance, I've tried the term "general," which, in "general linguistics" as Benveniste and others use it, opposes itself to both the universal rationalist linguistics of Chomsky and the fragmented empirical linguistics of Bloomfield and his followers (see Schleifer 1987: Ch 2). I've also tried "analogy" as opposed to hierarchical ordering implicit in most tropological figuration and "alternative" as opposed to "simultaneous" in Heisenberg's description of quantum mechanics (see Schleifer 1991). And, in the most general way (working with my colleagues Robert Con Davis and Nancy Mergler), I've tried "emergent understanding" as opposed to the Enlightenment (and Kantian) definition of understanding as the harmony among the criteria of generalization, simplicity, and exhaustiveness used to describe the transcendental value of scientific theories (see Schleifer et al 1992). In this instance, as in Benveniste, the focus is on the ability of science to generalize across cases and, simultaneously, to situate itself within general, but not universal, modes of understanding -- modes particular to the historical moment of its articulation. 
In all these terms, my attempt has been to make a place for what Raymond Williams calls "common experience" as opposed to both fragmented "individualism" and monumental "universal" experience. The reason for my trouble -- it is also the trouble of "rethinking culture," as the title of our conference suggests -- is that cultural studies itself is, as Samuel Weber says of the humanities, "the participation in and imparting of the particular, the partisan, and the partial" (1987: 144). At the same time, however, Weber asserts, the humanities is (are?) precisely this complex activity "that spans a society, from its 'most cultivated part' to its 'crudest,' and holds it together" (1987: 144). That is, cultural studies is forcing us to "rethink" the relationship between the part and the whole, partisanship and truth, particularity and meaning, and the difficult relationship -- which is the difficulty of every ethics -- between what is general and common and what is parochial and interested. Such rethinking, I believe, requires that we reimagine the definition and functioning of institutions.

One way to begin this rethinking of both culture and institutions is to acknowledge explicitly the partial nature of cultural studies. "Cultural analysis," Geertz writes,

is intrinsically incomplete. And, worse than that, the more deeply it goes the less complete it is. It is a strange science whose most telling assertions are its most tremulously based, in which to get somewhere with the matter at hand is to intensify the suspicion, both your own and that of others, that you are not quite getting it right. But that, along with plaguing subtle people with obtuse questions, is what being an ethnographer is like.

There are a number of ways to escape this -- turning culture into folklore and collecting it, turning it into traits and counting it, turning it into institutions and classifying it, turning it into structures and toying with it. But they are escapes. The fact is that to commit oneself to a semiotic concept of culture and an interpretive approach to the study of it is to commit oneself to a view of ethnographic assertion as . . " "essentially contestable." (1973: 29)

Such contestation, I think, might very well direct the ways cultural studies can be instituted in the university, in the larger domains of knowledge, and in particular societies as well. I even imagined, when I was thinking about this panel, of discussing ethics in relation to the assertion of Emmanuel Levinas that one's "ethical relation to the other" is prior to both ontology and aesthetics, and, like cultural studies, with its generalizations, analogies, or focuses on emergent knowledge or "common experience," traverses other 
modes of inquiry. The development of such an ethics, I believe, suggests a mode of institution that is neither universalizing nor simply particularizing. In Keywords, Williams includes <<institution>> as "one of several examples (cf. culture, society, education) of a noun of action or process which became at a certain stage, a general and abstract noun describing something apparently objective and systematic" (1983: 168).

In his description of cultural analysis, Geertz presents four institutional modes as the forms of escapism pursued in the face of the incompletion -the historical and metonymic endlessness -- of cultural studies. What is being "escaped," in fact, is the <<activity>> - -- Williams' "noun of action or process" -- of analysis and institution. Geertz gives four examples of this escape: the collection of folklore that, like the canonization of literature and art, attempts to encompass a cultural tradition as "timeless" (see Williams on "the culture of the selective tradition" [1961: 49f]); the enumeration of cultural traits that, like scientifically-modelled social sciences, attempts to define culture positivistically; the description of social institutions that, like Marxist and other socio-historical analyses, attempts to see culture in terms of relationships of production and power (see Johnson 1987: 53-58); and the apprehension of intellectual structures that, like semiotics, attempts to understand culture in terms of a hermetic logic of signification (Johnson 1987: 58-65).

These categories or "escapes" participate in the tendency of institutions to universalize and (in Greimas's term) to "substantialize" activities into objects of knowledge, what Williams calls the "persistent tendency to describe living processes in terms that confer on them the apparent status of fixed and separable objects. The terms we need, to describe the experience adequately," he continues, "must be essentially active, yet every new description we invent seems to turn, more or less rapidly, into an object" (1961: 93; see also Davis and Schleifer 1991: 40-41). It is precisely this tendency of institutionalization that led Henry Giroux, David Shumway, Paul Smith and James Sosnoski to describe the impossibility of establishing a $<<$ discipline $>>$ of cultural studies since institutional disciplines are characterized by "their capacity simultaneously to normalize and hierarchize, to homogenize and differentiate" (1984: 474). It a completely different way, it led Carey Nelson to articulate a "first draft of one version of a cultural studies manifesto" that counts fourteen points (like Ezra Pound's "do's and don'ts") of cultural studies (1991: 31-34). It also led the Chicago Cultural Studies Group more recently to note "the pressure to fix cultural criticism: to make it a 'studies,' a method, a content, a reproducible knowledge, a canon, a discipline, a politics, or a curriculum" (1992: 531), and to respond by articulating the question of how to rethink culture, not as a timeless set of categories and structures but as a mode of making boundaries and connections between and among existing modes of cultural cognition. Their explicit answer is to rethink "cultural studies" as "critical multiculturalism" in which "critical intellectual work ... cannot simply be exported from one context to another" (1992: 536). Finally, it led Richard Johnson to offer his sweeping description of the large number of powerful 
continuities "wrapped up in the single term 'culture,' which remains useful not as a rigorous category, but as a kind of summation of a history" (1987: 42). These responses to the substantification of institutions correspond, more or less, to Geertz's four categories of toying with structures of power, counting traits, classifying institutions, and collecting examples.

Two of these categories -- those of collecting a tradition and the apprehension of intellectual structures -- encompass what Williams calls the "'inner' process" of culture; while the others -- scientific positivism and historical institutionalism -- encompass what he calls the "general process" of culture. In Marxism and Literature Williams specifically describes the "complexity of the concept of 'culture'" I am trying to spell out here. The complex history of the term "culture," he writes, is

remarkable. It became a noun of 'inner' process, specialized to its presumed agencies in 'intellectual life' and 'the arts.' It became also a noun of general process, specialized to its presumed configurations in 'whole ways of life.' It played a crucial role in definitions of 'the arts' and 'the humanities,' from the first sense. It played an equally crucial role in definitions of the 'human sciences' and the 'social sciences,' in the second sense. Each tendency is ready to deny any proper use of the concept to the other, in spite of many attempts at reconciliation. (1977: 17)

For Williams, then, "culture" encompasses the possession of an individual subject's "inner" world and of a society of individuals conceived as a whole greater than the sum of its parts. It describes the ways in which societies make sense of the common experience of its members, situating "culture" within the domain of "ideas," and, in Williams' repeatedly phrase, it describes "a whole way of living of a people" (1958: 83; see Hall 1980: 58-59). In both conceptions, to add to the complexity of "culture," it can be understood in terms of what has come to be called the "aesthetic ideology" of $<<$ disinterested $>>$ contemplation or it can be understood as a concept that makes something happen in a manner that is historically and functionally effective. Within each of these alternatives the concept and processes of culture remain, for Williams, tied to particular historical events. Throughout Culture and Society Williams argues that the "idea" of culture, beginning with Burke in the eighteenth century, is a response to the growing industrialism of Britain, and more specifically, to the fragmented individualism of laissez faire capitalism. In a similar analysis, Cornel West argues that Matthew Arnold is the harbinger of modernism precisely because he is one of the first to recognize that the traditional ideology of the Occident - -- and especially the religious ideology that sustained the great "centering" of world political and social power in Europe from 1492 until the triumph of liberal capitalism in the nineteenth century -- no longer authoritatively sustains the European polity as a whole (1988). 
Cultural studies, however, is historical in another sense as well. What Geertz calls the "essentially semiotic" concept of culture he develops (1973: 5) seeks to rescue social discourse "from its perishing occasions and fix it in perusable terms" (1973: 20). That is, it attempts to avoid imprisonment "in the immediacy of its own detail" (1973: 24) without falling into vacuously abstract generalizations. The collections of folklore or of the "facts" of positive science present the danger of detail; the abstractions of structuralism or of grand institutional histories present the danger of unsubstantial universals. Against these dangers, Geertz suggests that the "thick descriptions" of cultural studies, seeking "a stratified hierarchy of meaningful structures" (1973: 7), can only be achieved by situating the events we call culture within the particularities of historical understanding. For Geertz within cultural analysis "the essential task of theory building ... . is not to codify abstract regularities but to make thick description possible, not to generalize across cases but to generalize within them" (1973: 26).

Williams pursues and achieves such an analysis in his tracing of the great nineteenth-century articulations of "culture" as a concept in Culture and Society. That is, he generalizes $<<$ within $>>$ a case, but widens that "case" to include "a whole way of living of a people" by mapping, as he says, wide "changes in life and thought" (1958: xiii) in the historically changing uses of this concept. Such mapping defines the historicity of cultural studies that is neither the prisoner of positive detail nor the working out of transhistorical destinies. (Bakhtin's dialogical aesthetics attempt a similar complex historiography as do Derrida's conceptual grammatologies.) Moreover, such mapping presents a $<<$ genealogy $>>$ of the concept of culture in Nietzsche's sense of genealogy as the tracings of transformations rather than the pursuit of authoritative "causes." Genealogy is a noun of general process, but when it is assimilated to an inner process, we can profitably use Derrida's rewriting of Nietzsche's term in his word "grammatology." Both terms, I think, apply to William's and Geertz's pursuit of cultural stu- dies. They apply also to Foucault's reading of Nietzsche's term. Genealogy, Foucault writes, is a "patiently documentary" enterprise that does not assume that words have kept their ("invariant") meanings. Rather, it attempts to

record the singularity of events outside any monotonous finality; it must seek them in the most unpromising places, in what we tend to feel is without history -- in sentiments, love, conscience, instinct; it must be sensitive to their recurrence, not in order to trace the gradual course of their evolution, but to isolate the different scenes where they engaged in different roles. (1977: 139-40)

Cultural studies attempt to bring historical consciousness -- including the history of conceptual, psychological, and linguistic formations as well as social formations -- to "what we tend to feel is without history." In his 
cultural studies, Williams traces the $<<$ genealogies $>>$ of key words in order to isolate the different scenes where they engage in different roles by asking obtuse questions -- in Brecht's imperative mode of "thinking crudely" -- of subtle concepts and social formations.

\section{II}

Tracing "singularities" in history or semantics, like the postulating of singularities in physics or Geertz's privileging of special cases, raises all the problems of the relationship between knowledge and institutions. How, in fact, can "cultural studies" be instituted? Are its "main features," as Richard Johnson says, "its openness and theoretical versatility, its reflexive even selfconscious mood, and, especially, the importance of critique" (1987: 38)? Is it, as Patrick Brantlinger suggests, "a unified, inter- or anti-disciplinary theory and practice that, for lack of a better name, is now often called cultural studies" (1990: 16)? Must cultural studies develop, as Susan Stewart argues, "new formal objects of critique .... [such as] vertigo, boredom, repetition, surplus, speed, inversion, passivity, intensity, distraction, and monumentality" (1989: 12)? Such institutionalization takes the form of articulating a discipline -- what Foucault calls "an order of discourse" -- in which, as Weber has noted, the $<<$ problem $>>$ is the relationship between the part and the whole, the relationship between "cases" and the discipline which define them as cases. To generalize within cases, as Geertz says, is to participate in local and close readings, the "thick descriptions" of literary criticism (for instance) that eshews global statements. It is to be particular, partisan, and partial. On the other hand, $<<$ institutionalization $>>$-- at least in the United States -- creates the constant pressure for universalizing $<<$ across $>>$ cases within a discipline: disciplinarity itself (and the plurality of co-existing disciplines within the university) functions by universalizing experience across the cases it defines and analyzes. For this reason Weber argues that

the University universalizes, individualizes, and in the process excludes conflict as far as possible. Or rather, it delegitimizes conflict, in the name of pluralism. Pluralism allows for a multiplicity of coexisting, even competing interpretations, opinions, or approaches; what it does not allow is for the space in which these interpretations are held to take place to be itself considered conflictual. (1987: 42)

In this description the University as an institution is structured in the way that Gerald Graff describes the English Department as an institution: a site where competing interpretations, opinions and approaches can coexist without discussion (1987: 11). Lately, when we were restructuring the English major at the University of Oklahoma, members of the Anthropology 
Department complained to the College of Arts and Sciences that the term "culture" was a technical one within Anthropology and its use in the titles and descriptions of English Department courses was worthy of a formal protest. The University itself has mechanisms for such protests, and they are designed, on pragmatic grounds, to encourage compromise and settlement rather than interdisciplinary debate.

The most pragmatic "ground" is the working assumption of what Weber calls "the $<<$ absolute autonomy of the individual discipline $>>$, construed as a self-contained body of investigative procedures and of knowledge held to be universally valid within the confines of an unproblematized field" (1987: 147). That is, the pragmatic ground is that, in Stanley Fish's words, "Being Interdisciplinary is so Very Hard to Do." In fact, Fish argues, it is impossible (1989: 19). Donald Davidson, in a very different register, makes the same argument. "It is one thing, " he writes, "for developments in one field to affect changes in a related field, and another thing for knowledge gained in one area to constitute knowledge of another" (1980: 247). This inability of knowledge to be transfers across disciplines -- like Geertz's argument that generalizations cannot be made across cases within the study of culture -raises all the problems of instituting cultural studies within the University.

Weber suggests a response to this problem when he attempts to describe "<<another $>>$ kind of institution" modeled on Freud's sense of "ambivalence" that "entails not merely the static opposition of conflicting emotions, but rather a constantly shifting dynamic of drive and prohibition" (1987: 149, 148). Freud's description itself, I might say, is modeled on -- or rather, <<analogous to >> - -- the definition of "interpretation" Greimas and Courtés offer in Semiotics and Language: within a modernist tradition of "interpretation" identified with Saussurean linguistics, Husserlian phenomenology and Freudian psychoanalysis, "interpretation . . . is a paraphrase which formulates in another fashion the equivalent content of a signifying element within a given semiotic system" (1983: 159). In these terms, an institution can be conceived as a field of interpretation, a discipline that is not "absolutely autonomous" even while its lack of autonomy does not require its $<<$ subordination $>>$ to another disciplinary field. Such a discipline institutes, ambivalently, both exclusitory practices that $<<$ make it $>>$ a "discipline" and critiques of those very practices by means of its modes of interpretation, its importation of analogical discourses. Finally, the procedures and knowledge of such an instituted discipline are not quite "self-contained" precisely because, in Davidson's words, they can be "affected" by knowledge from other fields.

This new "kind of institution" can be realized by applying "alternatively," in Werner Heisenberg's description of quantum mechanics, "different classical concepts which would lead to contradictions if used simultaneous" (1958: 
179). In this conception, the opposition between generalizations across cases and generalizations within cases that Geertz describes is momentarily neutralized just as Williams neutralizes it in the general sweep of Culture and Society. That is, the opposition between the local case and the general case is blurred even while the opposition between the local and the universal is maintained. If "classical" displinarity, as Weber says, calls for a "self-contained body of investigative procedures and of knowledge held to be universally valid within the confines of an unproblematized field," then another kind of institution calls for the alternation of local and general validity across fields. Such "fields" are precisely problematized by the fact that knowledge and procedures are occasionally general, occasionally local, and these alternatives, like the ethics with which I began, are a function of the particular cases and values being examined.

Recently at the University of Oklahoma we restructured the English major in ways that, retrospectively, can be understood in terms like these.

(Analogously, Heisenberg says that "quantum theory always enables us to give full reasons for the occurrence of an event after it has actually taken place" [1952: 56-57]). We replaced a major emphasizing literary history (though it had genre courses and courses in transhistorical special topics) with a three track major that allows students to follow one or two of three "tracks" in "Literature," "Writing," and "Critical Theory/Cultural Texts" after taking one of three two-course literature surveys in English, American or World literature and a two-course sequence in literary analysis and cultural studies. The third track cost us the most energy and argument -- all eighteenth new courses we added (including those whose use of the term "culture" were protested by the Anthropology department) are in this "track" -- which aims, as our final description notes, "to introduce students to a number of critical approaches -- for example, historical, feminist, psychological, and cross-cultural -- which can be brought to bear on a variety of literary and nonliterary works that can be called cultural texts in the largest sense." To this end, we further divided this track into three general areas, "Cultures in History, Systems of Representation, Questions of Theory and Value." We had imaged, as we discussed institutionalizing this track, that multiculturalism should be another general area, but we simply did not have faculty to staff this area.

The three areas we described delimited different "disciplinary" fields in the following way:

"Cultures in History >>: Courses under this heading chart the intricate links between cultural activity and social history. . . . They are designed to identify the ways that reading and writing are implicated in and transform the social and cultural formations in which they operate." 
"<<Systems of Representation $>>$ : Courses under this heading examine how systematic forms of representation govern the generation of meaning and how individuals or cultures use such systems to communicate value. . . . These courses will also explore how cultural institutions sustain systems of representation, and how culturally constructed meanings can gain the status of self-evident naturalness."

"<<Questions of Theory and Value $>>$ : Courses under this heading ask students to study a variety of theoretical approaches to discourse or culture, and to consider the range of aesthetic, philosophical, social, or political values attached to critical analysis."

These tracks, we think, present procedures and knowledge that are general and analogous without precluding $<<$ local $>>$ critique. That is, in all three areas -- as in the Literature and Writing tracks as well -- "reading and writing" is presented as a "general" concern. Such generality, however, does not preclude the study of (more or less) local events of reading and writing in the first area (in courses such as $<<$ The Literature of Empire $>>$ and $<<$ American Indian Nonfiction Writing $>>$ ); the (more or less) particular conditions governing those events in the second area (in courses such as $<<$ Linguistics and Semiotics $>>$ and $<<$ Science and Cultural Texts $>>$ ); the (more or less) partisan values in the third area (in courses such as $<<$ Periods and Periodization $>>,<<$ Authors, Canons, and Canon Formation $>>$, and $<<$ Feminist Cultural Studies $>>$ ); and the partial analogies among procedures and knowledge across these areas.

\section{III}

The problem we faced -- that we all continually face -- is the problem I mentioned in the beginning of "rethinking" the relationship between the part and the whole, partisanship and truth, particularity and meaning. Recently, Edward Said addressed this problem in narrating his own experience of the conflict between partisan and truth in an essay entitled "The Politics of Knowledge." Describing a conference he attended where he was attacked by one participant for citing only white men in the first thirteen pages of a paper on European imperialism and by a second participant by not describing the positive results of imperialism, Said notes that he was reminded that "in matters having to do with human history and society any rigid theoretical ideal, any simple additive or mechanical notion of what is or is not factual, must yield to the central factor of human work, the actual participation of peoples in the making of human life" (1992: 176). Such participation is local and particular, but the "human life" Said describes is general and generalizable. In fact, Said is describing the two cultures of cultural studies I am examining. In his "key word," << worldliness $>>$, he 
attempts to sum up the complexity of cultural studies and its institutions. Speaking of literature -- including, I think, the wider senses of reading and writing we have described in our new curriculum -- he discusses the usefulness of his term.

By linking works to each other we bring them out of the neglect and secondariness to which for all kinds of political and ideological reasons they have previously been condemned. What I am talking about therefore is the opposite of separatism, and also the reverse of exclusivism. It is only through the scrutiny of these works $<<$ as $>>$ literature, as style, as pleasure and illumination, that they can be brought in, so to speak, and kept in. Otherwise they will be regarded only as informative ethnographic specimens, suitable for the limited attention of experts and area specialists. $<<$ worldliness $>>$ is therefore the restoration to such works and interpretations of their place in the global setting, a restoration that can only be accomplished by an appreciation not of some tiny, defensively corner of the world, but of the large many-windowed house of human culture as a whole. (1992: 185)

Said goes on to call this work both unprovincial and interested. This difficult combination of the local and the general -- the "thick descriptions" within cases Geertz describes and the common experience that Williams pursues -helps define the kinds of institutions that cultural studies calls for and may allow us (the results are still up for grabs) to create institutions of cultural studies.

The results will always be up for grabs because, above all, the institutions of cultural studies are always $<<$ provisional $>>$ in that they always respond to local conditions of contest and strength. This, in large measure, is the implication of Geertz's assertion that cultural analysis is intrinsically incomplete. In a sense, cultural studies calls for institutions that are the opposite of those which Gulliver encounters in his third voyage established by men whose sense of transcendental "reason" overwhelms what Swift calls the common actions and behaviors of life. The men of Laputa believe that institutions serve whatever is unchanging in human affairs, whatever is, by this definition, $<<$ unworldly $>>$. Like Kant's faculties of the university Derrida describes in "The Principle of Reason" that aim "to remove the university for 'useful' programs and from professional ends" (1983: 18), Laputans have no problem separating the "pure" from the practical, and they have little difficulty designing institutions that will remain "pure." They have little difficulty because they think that their experience is transcendental experience, and that the forms of knowledge and experience they have discovered will be true forever. Like the Kantian subject of knowledge, they assume they will live forever. (This, I think, is the force of Swift's satire in presenting the Struldbruggs.) Such traditional institutions, Derrida says, "always, willingly or not, find [themselves] serving unrecognized ends, reconstituting powers of caste, class, or corporation" 
(1983: 18); they "erect a barricade against the future" (1983: 19). The institutions of cultural studies, on the other hand, do not achieve such purity because its institutions are not simply a reflection on other forms of knowledge and association and reality. Rather, cultural studies calls for "worldliness" that combines human and worldly affairs -- Said's interests and unprovinciality -- in the interested and transgenerational work of culture and cultural institutions.

The work of institutions, I think, serve historical moments but also, existing within a society of individuals, they serve also more than a single moment -they involve the very "future" Derrida mentions. That is, while they serve those who work within them, they also serve other generations and other historical moments, not simply as forms for knowledge and association, but also as a form of mastery to bequeath, as a kind of "cultural" inheritance, to those who come afterwards. In describing the relationship between capitalism and nature in One-Way Street, Walter Benjamin offers the analogy of generational relationships. "Who would trust a cane wielder who proclaimed the mastery of children by adults to be the purpose of education?" he asks. "Is not education above all the indispensable ordering of the relationship between generations and therefore mastery, if we are to use this term, of that relationship and not of children?" (1978: 93). In this passage, as in much of his work, Benjamin brings together different generations in one glance or phrase to underline the temporal disparity encompassed by culture. In "N [Re The Theory of Knowledge, Theory of Progress]" Benjamin spells out further the institutional implications of the "incomplete" nature of cultural studies I began with. Responding in his notes to a letter from Max Horkheimer in 1937 in which Horkheimer accused Benjamin of being idealistic in his assertion of "incompleteness . . . if completeness isn't included in it" since "past injustice has occurred and is done with. The murdered are really murdered" (1989: 61), Benjamin replies:

The corrective to this way of thinking lies in the conviction that history is not only a science but also a form of remembrance. What science has 'established' can be modified by remembrance. Remembrance can make the open-ended (happiness) into something concluded and the concluded (suffering) into something open-ended. This is theology; however, in remembrance we have an experience which forbids us from conceiving of history fundamentally a-theologically, despite the fact that we are hardly able to describe it in theological concepts which are immediately theological. (cited in Wolin 1989: 225; also translated in Benjamin 1989: 61)

For Benjamin's term "theological," I would substitute "ethical." That is to say, I would add that his "form of remembrance," the ordering of the relationship between generations, finally constitutes culture in its creation and imputation of value across particular experiences. Such imputation is not universal but "general," a form of analogy, a dialogue of alternative explanations. The institutions of cultural studies create a place for the 
activities of imputations that are always repeated but never the same. They do so provisionally, by allowing those who come after to finally judge their worth and the value of their interested struggle. In cultural studies, then, we confront experience which forbids us from conceiving of institutions of knowledge as fundamentally disinterested and from conceiving of knowledge itself as fundamentally non-ethical. If we can do it -- as I said, it's still up for grabs -- cultural studies may be able to establish institutions that are interested and unprovincial. As in quantum mechanics, only retrospectively, by those who inherit and transform our institutions, will we be able to say. $>>$

\title{
Ronald Schleifer
}

\section{Department of English}

\author{
University of Oklahoma
}

Norman, OK 73019

Surface Page d'Acceuil/Home Page

\section{Works Cited}

Benjamin, Walter (1979) One-Way Street and Other Writings. Trans. Edmund Jephcott and Kingley Shorter. London: New Left Books.

. (1989) "N [Re the Theory of Knowledge, Theory of Progress]," trans. Leigh Hafrey and Richard Sieburth. In Benjamin: Philosophy, Aesthetics, History, ed. Gary Smith, 43-83. Chicago: University of Chicago Press.

Chicago Cultural Studies Group. 1992. "Critical Multiculturalism." Critical Inquiry, in press.

Davidson, Donald. 1980. Essays on Actions and Events. New York: Oxford University Press.

Davis, Robert Con, and Ronald Schleifer. 1991. Criticism and Culture: The Role of Critique in Modern Literary Theory. London: Longman.

Derrida, Jacques. 1983. "The Principle of Reason: The University in Eyes of its Pupils," trans. Catherine Porter and Edward Morris. Diacritics 19: 3-20. 
Fish, Stanley. 1989. "Being Interdisciplinary Is So Very Hard to Do." Profession 89, ed. Phyllis Frankin. New York: Modern Language Association. $15-22$.

Foucault, Michel. 1977. "Nietzsche, Genealogy, History." In Language, Counter-Memory, Practice, trans. Donald Bouchard and Sherry Simon. Ithaca: Cornell University Press. 139-64.

Geertz, Clifford. 1973. The Interpretation of Cultures. New York: Basic Books.

Giroux, Henry, David Shumway, Paul Smith, James Sosnoski. 1984. "The Need for Cultural Studies: Resisting Intellectuals and Oppositional Public Spheres." Dalhousie Review, 64: 472-86.

Graff, Gerald. 1987. Professing Literature: An Institutional History. Chicago: University of Chicago Press.

Greimas, A. J., J. Courtés. 1983. Semiotics and Language, trans. Larry Crist, Daniel Patte, et al. Bloomington: Indiana University Press.

Heisenberg, Werner. 1952. Philosophic Problems of Nuclear Science, trans. F. C. Hayes. New York: Fawcett World Library.

1958. Physics and Philosophy. New York: Harper and Brothers.

Johnson, Richard. 1987. "What is Cultural Studies Anyway?" Social Text, no. 16: 38-80.

Kimball, Roger. 1992. "The Periphery vs. the Center: The MLA in Chicago." In Debating P.C., ed. Paul Berman. New York: Dell Publishing. 61-84.

Nelson, Carey. 1991. "Always Already Cultural Studies: Two Conferences and a Manifesto." Journal of the Midwest MLA 24: 24-38.

Said, Edward. 1992. "The Politics of Knowledge." In Debating P.C., ed. Paul Berman. New York: Dell Publishing. 172-89.

Schleifer, Ronald. 1987. A. J. Greimas and the Nature of Meaning. Lincoln: University of Nebraska Press.

-------- . 1991. "Analogy and Example: Heisenberg, Negation, and the Language of Quantum Mechanics." Criticism 33: 285-307.

Schleifer, Ronald, Robert Con Davis, Nancy Mergler. 1992. Culture and Cognition: The Boundaries of Literary and Scientific Inquiry. Ithaca: Cornell University Press.

Stewart, Susan. 1989. "The Interdiction." Profession 89, ed. Phyllis Frankin. New York: Modern Language Association. 10-14.

Weber, Samuel. 1987. Institution and Interpretation. Minneapolis: University of Minnesota Press. 
West, Cornel. 1988. "Historicizing the Postmodern Debate: Arnold, Eliot, Trilling, and Fannon on the Crisis in Modern Culture." Unpublished lecture presented at the University of Oklahoma November 2, 1988. Videotape on file, Honors Program.

Williams, Raymond. 1958. Culture and Society. New York: Columbia University Press.

------- . 1961. The Long Revolution. New York: Columbia University Press.

. 1977. Marxism and Literature. New York: Oxford University Press.

--------- . 1983. Keywords. Revised edition. New York: Oxford University

Press.

Wolin, Richard (1989) "Experience and Materialism in Benjamin's Passagenwerk." In Benjamin: Philosophy, Aesthetics, History, ed. Gary Smith, 210-27. Chicago: University of Chicago Press.

Acknowledgements

The discussion of culture in Part I of this essay is indebted to Criticism and Culture: The Role of Critique in Modern Literary Theory by Robert Con Davis and Ronald Schleifer (1991), especially chapters 1 and 7. I would also like to acknowledge the efforts and support of the cultural-studies working group at the University of Oklahoma. The group includes Richard Barney, Hunter Cadzow, Robert Con Davis, Aparna Dharwakher, Vinay Dharwadker, Yvonne Fonteneau, Susan Green, David Gross, Geary Hobson, Henry McDonald, Catherine Peaden, Alan Velie, and myself. Working together and in concert with other members of the English Department, we developed the new major curriculum described in Part II. 